\title{
Alt det der med vagina dentata kan man godt putte skråt op \\ - Interview med Henning Bech og Vivi Hollænder
}

Seksualiteten er ikke universel; den har altid været bundet til bestemte kulturelle og diskursive kontekster. Enhver tale om seksualiteten i bestemt form ental er derfor en tilsnigelse, der i værste fald slet ikke formår at favne den kompleksitet, der ligger $\mathrm{i}$ den menneskelige seksualitet og dens italesættelser. Ikke desto mindre er det et drivende bagvedliggende spørgsmål for dette Slagmark-nummer, hvad vi egentlig forstår ved seksualitet(-er) $\mathrm{i}$ en vestlig kontekst $\mathrm{i}$ dag.

Italesættelsen af det seksuelle kan i dag synes fuldstændig overladt enten til pornoindustrien eller diverse selvudnævnte sexeksperter - ofte med rent kommercielle interesser $i$ at udbrede deres budskaber om sex og erotik. Samtidig peger mange forskere - således også i dette nummer af Slagmark - på, at der er opstået en nypuritansk og moraliserende bølge af meningsdannere, der er hurtige til at udnævne ofre for drifter og lyster.

For at få et samtidsdiagnostisk blik på seksualiteten har Slagmark rettet en række spørgsmål til to førende eksperter i seksualitet. Professor og seksualitetsforsker Henning Bech (HB) er ansat på Sociologisk Institut på Københavns Universitet og Vivi Hollænder (VH) er sexolog og seksualvejleder med egen praksis. Formålet med interviewet er dels at få en klinisk og dels en samfundsanalytisk belysning af forholdet mellem køn, drift, krop og politik, der stikker dybere end de ofte endimensionelle fremstillinger i populærmedierne. Bechs og Hollænders forklaringer illustrerer det paradoks, at den øgede eksponering af seksualiteter ikke har gjort os nær så frigjorte som vi tror.

\section{Seksualiteten og kønnet:}

\section{- Er konnet en konstruktion eller et biologisk faktum?}

VH: Det er begge dele. Vi fødes med visse kønsspecifikke træk og egenskaber, men gennem kultur og opdragelse kan disse påvirkes i mere 
eller mindre grad. Selv om samfundsstrukturen har stor indflydelse på vores adfærd som køn, ser vi hvordan de grundlæggende biologiske mekanismer alligevel påvirker vores indbyrdes ageren. Hvilket i mine øjne ikke er spor mærkeligt.

HB: Samfunds- og kulturvidenskaberne har ingen metoder til at besvare dette spørgsmål udtømmende - hverken med hensyn til kønnet eller til seksualiteten. Men man kan undersøge historiske ændringsprocesser og kulturelle variationer. Og meget af det, som mange troede var biologisk bestemt, har vist sig at være så foranderligt, at det ikke er holdbart at anse det for biologisk determineret. På den anden side skulle det da være mærkeligt, hvis biologien ikke havde en del at gøre med, at nogle mennesker - cirka halvdelen af menneskeheden - udvikler organer, der under visse omstændigheder sætter dem i stand til at føde børn. Og at cirka den anden halvdel udvikler organer der, under visse omstændigheder, kan medvirke til, at der sprøjtes sæd ud. Men man skal altid huske på, at det ikke følger af dette, at de førstnævnte skal føde børn, ej heller hvor og under hvilke omstændigheder de sidstnævnte skal sprøjte sæd. Det er heller ikke givet, at denne forskel skal tillægges den altafgørende rolle $\mathrm{i}$ forbindelse med overvejelser over, hvad køn og seksualitet er.

\section{Sex i praksis:}

- Konnet insisterer på at praktisere, men enbver seksualpraksis er kendetegnet ved forskellige retningslinjer, regler og forbud. Hvad kendetegner - og hvad former vor seksualpraksis $i$ dag $i$ Vesten?

VH: På trods af at flere og flere eksperimenterer med alternative livsformer og eksperimenterer med deres seksuelle udtryksformer og praksisser, er det stadig det monogame forhold mellem mand og kvinde, der er normen, og som dominerer vores syn på seksualiteten. Vi er ikke længere arbejdsmæssigt og økonomisk afhængige af hinanden, seksualiteten og de gensidige følelser er i dag den bærende kraft i parforholdet. Vi stiller derfor store krav og forventninger til den side af samlivet. Vi dyrker den romantiske forestilling om, at vi automatisk kan og bør tilpasse vores seksuelle lyster og derved være i stand til at opfylde og tilfredsstille hinandens behov resten af livet. Det er meget store krav at stille til parforholdet og $\mathrm{i}$ praksis viser det sig jo også, at det er svært at leve op til. 
HB: På den ene side er seksualpraksis kendetegnet ved en stor variation, som igen ikke kun er noget, der eksisterer i eller er skabt af "diskurser". På den anden side en rasende moralisme, der vil have store samfundsmæssige magter - Staten, Politikerne, Feminismen - til at forbyde stadig flere udfoldelser.

- En nylig undersogelse lavet af Ramboll for Jyllandsposten om danskernes sexliv viste, at hver tredje af de adspurgte mente, at de fär for lidt sex. Der er noget der tyder på, at sex $i$ dag er den store taber $i$ konkurrencen med andre aktiviteter og goremal $i$ bverdagen. Stemmer det overens med hvad du horer i din praksis?

VH: Absolut, ja - vores liv er i dag fyldt op med så mange krav om karriere, børn, fritidsaktiviteter, et smukt og veltrimmet ydre, et perfekt hjem og socialt samvær med familie og venner, at man kun orker at falde sammen foran TVét, når man endelig har en ledig stund. Sexlivet bliver prioriteret allernederst. Og det gør det, fordi vi har nogle urealistiske forestillinger om, at sexlysten skal komme dumpende spontant og ramme begge parter på samme tid og sted. Det gør den kun i forelskelsesfasen - derefter må man selv arbejde på at give den plads og det overser man nemt, når hverdagens gøremål fylder døgnets timer.

Det kan forekomme absurd, når det bliver sexologens opgave at finde bare en eller to timer $\mathrm{i}$ folks tidsskemaer, hvor de sammen kan arbejde for at genfinde sexlysten. Men ikke desto mindre er det ofte tilfældet.

Nogen gange kan man spørge sig selv, hvorfor det er vigtigere at tilbringe 5 timer i træningscenteret for at få den perfekte krop, hvis den selv samme krop aldrig bliver brugt i erotikkens tjeneste sammen med den man elsker?

Er det fordi vi prioriterer det, der er synligt for andres øjne, højere end intimiteten i parforholdet?

\section{Tabuer og seksualmoral:}

Hvordan er de danske kvinders forhold til deres kusse?

VH: Det er mit indtryk, at kvinder i dag har en øget opmærksomhed på deres kusser og det er både godt og skidt. Det er godt, når opmærksomheden bruges positivt til en bedre kropskontakt, selvaccept og nydelse, men det er noget skidt, når det vendes til selvhad og væmmelse.

Jeg møder stadig voksne kvinder, som aldrig har set deres egne kønsdele og som væmmes ved at skulle se sig selv i et spejl og unge kvinder, der tror 
deres - helt normale - kusser er misdannede.

\section{- Eksisterer der seksualmoral $i$ dag? Hvordan fungerer den?}

VH: Jeg vil sige, at der eksisterer flere forskellige seksualmoraler i dag - afhængig af hvilke miljøer man færdes i. Det er ikke mit indtryk at seksualmoralen er generationsbestemt, men nærmere kulturbestemt.

Mennesker, der er tilknyttet subkulturer eller swingermiljøer, har f.eks. en anderledes seksualmoral end de, der vægter monogami og troskab højest, men begge steder er der en seksualmoral - de er blot forskellige.

HB: Det er vigtigt at skelne mellem moral eller etik på den ene side, og moralisme på den anden. Moral og etik har at gøre med at tage vare på sine partnere og sine omgivelser i øvrigt. Moralismen tordner for tiden så højt i Danmark, at det er blevet svært at komme til orde med en moralsk-etisk diskussion. Heldigvis forsøger mange mennesker dog at tage vare på deres nære og fjernere omgivelser.

\section{- Er der noget vort samfund ik.ke vil kendes ved i dag?}

VH: Ja, det er der i høj grad. Udover de seksualpraksisser, som er ulovlige og skadelige, er der stadig megen seksualitet, som er belagt med skyld og skam. Meget mere end man umiddelbart tror.

Mange mennesker skammer sig over deres lidt specielle lyster eller bare helt almindelige lyster- også selv om de måske er helt uskyldige og uskadelige. Vi har en indgroet angst for ikke at kunne leve op til normaliteten.

Det samme gælder alder, udseende og fysiske evner. Selv om det efterhånden er anerkendt, at alle mennesker er født med en seksualitet og at vi er seksuelle væsner til vi dør, er der stadig megen berøringsangst hvad angår gamle, syge, og handicappedes seksualitet.

Forestillingen om at sex hører til blandt de unge og smukke lever i bedste velgående.

HB: For moralismen er der stort set intet, som uden videre er acceptabelt. Alt - ALT - skal mistænkes for at være undertrykkende, udbyttende, usundt. Det går især ud over kvinder - for moralismen at se kan vi aldrig være sikre på, at kvinder ikke bliver undertrykt. Andre ville sige at hvad folk gør seksuelt, må de selv om, så længe de ikke for alvor skader nogen 
med det. Nogle vil i den forbindelse tale om, at sex skal være mellem samtykkende parter. Det er dog nok at forsimple sagerne for meget. Forførelse spiller også en ofte stimulerende rolle, og samtykke skal ikke antage karakter af at være en kontraktlig affære, hvor parterne skal afgøre alt gennem en sagligverbal kommunikation (som det kan se ud hos Giddens og Habermas). Det kan nemt være dræbende for lyst.

\section{- Skal der overhovedet eksistere seksuelle tabuer og tavshed om nogen emner?}

VH: Jeg tror, at der altid vil eksistere seksuelle tabuer. Tabuer er ikke en ensartet størrelse, der alle er af det onde. Nogle er nødvendige, andre er destruktive og skadelige - atter andre har en seksuel tiltrækningskraft i sig selv.

Hvis vi forestillede os at alle seksuelle tabuer pludselig blev nedbrudt, ville vi formentlig opfinde nogle nye.

HB: Man skal ikke altid tale om sex, mange gange skal man holde sin kæft. På den anden side er for meget tavshed ikke godt - det har vi prøvet i en del generationer før 68-generationen, og så smart var det heller ikke. Jeg mener selv, at der findes nogle seksuelle fænomener, som overskrider acceptable moralsk-etiske grænser, og som samfundet bør have forbud imod. Et eksempel er sex med døde. Ikke så meget fordi de ikke kan give deres samtykke, men fordi det støder mod den værdighed, respekt og højtidelighed, der tilkommer døden og de døde. Voksnes sex med små børn er et andet fænomen, som dog er meget komplekst. For eksempel hævdes det ofte, at det skal forbydes "af hensyn til børnene", fordi de får livsvarige traumer af det. Men der ikke noget, som tyder på at alle børn til enhver tid får livsvarige traumer af enhver form for seksuel kontakt med voksne. Faktisk ville hensynet til børnene ret beset i mange tilfælde påbyde, at man lod være med at gøre mere ved en affære, fordi det at trække børnene gennem et omfattende udspørge- og bekymringsmaskineri med en vis sikkerhed netop vil give dem traumer for livet. I øvrigt har frygten for pædofili antaget panikkens og hysteriets dimensioner; der er et uhyggeligt misforhold mellem skrækkens omfang og den reelle fare. Men det er et emne, som er vigtigt at diskutere, og det kan man ikke, når selve diskussionen allerede er tabuiseret. 


\section{Porno:}

- Spiller porno nogen rolle for hvad der i dag betragtes som normalt? Kan porno andre mands og kvinders opfattelse af seksualitet?

VH: Pornoen i sig selv er ikke nyskabende, men der sker en vekselvirkning mellem pornoen og det omgivende samfund. Pornoen afspejler fantasier, der altid har eksisteret og tilpasser dem tidens tendenser. Den synliggør vores tabuer og skyggesider, men der er tale om gammel vin på nye flasker. Det tidstypiske nu er at flaskerne er let tilgængelige for alle, og derved også påvirker vores opfattelse af seksualiteten - på godt og ondt.

Porno skal ikke opfattes som mere end det er: et middel til at øge den seksuelle lyst og inspiration til fantasien. Den har kun 2 sanser at spille på - den visuelle og den auditive og det bærer den selvfølgelig præg af. Den vil aldrig kunne konkurrere med, erstatte eller afspejle ægte sex mellem levende mennesker. Det skal man selvfølgelig være bevidst om og i et samfund med en god seksualoplysning vil det heller ikke være det store problem. Det er mere problematisk, hvis pornografi er eneste kilde til viden om seksualitet.

HB: Porno kan give inspiration, og den kan også blive ensrettende. Men hvorfor skulle mennesker ikke have lov til at gentage det samme og det samme på de seksuelle nydelsers område, og fremture i deres idiosynkratiske præferencer? Det psykiatrisk-psykologiske apparat vil så gerne kurere folk for deres angiveligt forfærdelige "afhængighed", "fikseringer" og "gentagelsestvang". Fra den anden kant fremfører queer-teorierne, som kritiserer "heteronormativitetens" missionære stilling, i virkeligheden ofte en "quero-normativitet" der er lige så formynderisk i sit krav om den totale foranderlighed og fleksibilitet.

\section{- Kan man forestille sig en pornoindustri med et frigorende potentiale?}

VH: Ja - det kan man sagtens. Vi er rigtig gode til at være bevidste forbrugere på andre områder. Hvis vi overfører den bevidsthed til brugen af porno, kan den både berige sexlivet og frigøre seksuelle potentialer - herunder nedbryde undertrykkende skamfølelser. Men det kræver, at man ikke lader sig nøje med elendige low-budget-produktioner, der sendes $\mathrm{kl} .3 \mathrm{om}$ natten på en tilfældig tv-station og tror at det er alt, hvad pornomarkedet har at byde på. Man kan f.eks. sætte sig ind i hvilke selskaber og 
producenter, der sikrer ordentlige arbejdsforhold for de medvirkende og undersøge, hvilke genrer, der stemmer bedst overens med ens egen seksualitet.

Det er en udbredt misforståelse at pornoen er stereotyp og kun skabt for og til mænd. Udvalget og mangfoldigheden har aldrig været større end det er nu, men det kan, som sagt, kræve research at finde det rigtige.

HB: Der er ikke noget i vejen for, at man kan tænke sig en porno - også en industrielt produceret porno - med anderledes persongallerier, rollefordelinger, plots, settings, remedier osv. end dem, der findes mest nu om dage. Her er internettet et godt opdagelses- og opdragelsesmiddel, for her findes der mulighed for at mangfoldige slags porno kan komme frem. Mænd der elsker med kvinder, kvinder der elsker med kvinder, mænd der bliver analbollet af kvinder med dildoer eller af maskiner, bliver fistfucked eller stikker metalrør ned i penis. Hvad mere vil man have?

- När et stigende antal unge kvinder valger at lade sig intimoperere, hvor konslaberne bliver opereret mindre - er det så et tegn på seksuel frigorelse (muligheden for at skabe sin krop som man vil) eller snarere et tegn pä, at pornoindustrien er vore dages mest magtfulde kulturindustri, der diketerer isar unge kvinders billede af, bvordan en kusse bor se ud?

VH: Man er tilbøjelig til at give intimbarberingen skyld for det ændrede syn på, hvordan en kusse bør se ud - ud fra en formodning om at kvinderne bliver forskrækkede over at kunne se deres kønslæber, når behåringen ikke længere skjuler dem. Jeg skal ikke kunne afvise, at der er noget om snakken, men helt så enkelt, tror jeg ikke det er.

Ønsket om blege kusser med minimale kønslæber er heller ikke udsprunget af mænds fantasier - tværtimod. Generelt holder mænd meget af kusser med alt, hvad der hører sig til.

Vi skal nok søge en væsentlig del af baggrunden i mainstream soft-pornoen fra USA. Playboy og andre amerikanske soft-porno-magasiner skal helst fremstå stuerene nok til at blive solgt på det bornerte og dobbeltmoralske amerikanske marked. - en af måderne er at fremstille nøgne kvinder som kønsløse voksmannequiner. Den amerikanske ungdom, der ikke er forvænt med seksualoplysning hverken i hjemmet eller i skolen har ikke meget andet end disse glamour billeder at spejle sig $i$.

Den kommercielle plastikkirurgiske industri hoppede hurtigt med på vognen - der er store økonomiske interesserer $\mathrm{i}$ at idealisere den næsten usynlige fisse og sygeliggøre det naturlige kvindekøn. 
Herfra har tendensen bredt sig videre til det øvrige porno-marked og til Europa og DK.

Kæmpe-fallossen har været dyrket som ideal siden tidernes morgen, hvilket pornoen også benytter sig af - det er den, der gør sig bedst visuelt. Igennem tiderne har mænd underkastet sig alverdens virkningsløse behandlinger og risikable operationer i håb om at nå de eftertragtede mål. Pengegriske læger og andre plattenslagere tjener tykt på mænds penis-forfængelighed og nu er turen desværre også kommet til kvinderne.

På samme måde som de store porno-pikke kan give mænd og drenge et forvrænget syn på deres egen pik, bliver pigerne også ramt, hvis porno udgør deres eneste referenceramme til, hvordan kønsdele ser ud.

Paradoksalt kan man konkludere, at des mere seksualfjendsk et samfund er og des mindre reel seksualoplysning, der er til stede, jo større er risikoen for at porno og et fordrejet billede af seksualiteten kommer til at dominere unges syn på seksualitet.

Jeg betragter ikke irreversible indgreb i de erogene zoner som seksuel frigørelse, med mindre det sker på lægelig indikation og gevinsten klart overstiger risikoen og ulemperne. Tværtimod. Man udvikler sit seksuelle potentiale hele livet og et hvert operativt indgreb indebærer risiko for uønskede bivirkninger på længere sigt. Med mindre der er tale om deformiteter, der påvirker livskvaliteten, er jeg imod varige kosmetiske indgreb i kønsdelene både hos mænd og kvinder, fordi det KAN gå galt og så er konsekvenserne for store.

HB: Mange er alt for bekymret over alt for meget. Ved uomgørlige kirurgiske indgreb er der dog for mig at se et reelt problem at tage stilling til. Problemet ligger imidlertid ikke i, om det er pornoindustrien, der har skabt efterspørgslen på kirurgi eller ej - men netop i uomgørligheden. I det nævnte tilfælde er det nok ikke et voldsomt problem, hvis ellers kirurgen er kvalificeret.

\section{- Er mainstream pornografien bange for den naturlige ubarberede kusse?}

VH: Jeg tror såmænd ikke at porno-industrien er bange for noget, der er efterspørgsel på. I øjeblikket er der mere efterspørgsel på det glatte look end på det hårfagre. Kropbehåringen er underlagt mode og kultur som så meget andet. Fjernelse af kønsbehåring er ikke noget enestående for vores tid eller kultur. I 70érne anså man en stor hårdusk for meget kvindelig og 
tiltrækkende og måske vil det igen være idealet om 10 år.

Men jeg ser også forsøg på at dæmonisere den glatbarberede kusse. At den skulle være et udtryk for kvindeundertrykkelse og mænds pædofile lyster. Det er efter min mening det rene vrøvl. En voksen kvinder ligner ikke en 12-årig, fordi hun barberer sin kusse og det er ikke undertrykkende at give sit køn opmærksomhed og eksperimentere med seksuelle udtryksformer.

Skulle det så også være udtryk for undertrykkelse og kvindelige pædofile tendenser, når så mange mænd barberer deres nosser? Næppe.

Forklaringen er nok snarere den, at mange oplever en øget følsomhed og lyst, når kønsdelene er nøgne $\mathrm{og}$ glatte $\mathrm{og}$ andre synes tillige, at det giver dem en form for hygiejnisk velvære.

Pornografien afspejler tidens trend og i øjeblikket er de behårede kusser i undertal - både i den virkelige verden og i pornoen, men de er bestemt ikke uddøde nogen af stederne.

HB: Mærkeligt nok glemmer mange, at visuel porno er til for at skulle ses. Så det er nok til dels en genre-nødvendighed, at man ser manden sprøjte sæd ud over kvinden (og ikke fx komme inden i kvinden), og at man ikke ser kvinden "komme" - der findes ikke et så utvetydigt visuelt udtryk for kvinders orgasme. Tilsvarende gælder måske også for den ubarberede kusse, hvis "tingen selv" ikke kan ses for bare hår. På et tidspunkt i pornoens historie har der i øvrigt været en generel tendens til, at alt hår ud over hovedbundshår skulle fjernes, også på mandekroppe. Alt det der med vagina dentata kan man godt putte skråt op.

\section{Mysteriet om 'Den lille død':}

- Hvad er der sket med forstaelsen af orgasmen inden for de seneste 30 ar? Eventuelt inden for de seneste 10 ar?

VH: Kvindens orgasme er blevet sat på dagsordenen. Fra at været næsten ikke eksisterende - i hvert fald ikke officielt - er den i dag nærmest et krav. Selvfølgelig var det positivt og befriende, at der blev sat fokus på kvindens nydelse og orgasme. Det var et kæmpe fremskridt på den seksuelle front. Siden da er udviklingen gået i retning af en præstationspræget orgasmejagt. I dag er det ikke længere nok at kunne præstere en enkelt klit-orgasme. Og det er ikke kun kvinderne, der er bekymrede, hvis de ikke er i stand til at opnå multi-, vaginal, g-punkts og sprøjte-orgasmer. Mændene måler også deres værd i kvin- 
dernes orgasmer.

Bagsiden af denne udvikling ses nu i form af seksuelle problemer i de forhold, hvor fokus har flyttet sig fra nydelse og liderlighed til orgasmeteknikker. De ønskede orgasmer udebliver eller kvinden mister lysten til sex, fordi det forventes hun leverer 3 orgasmer, inden manden giver efter for sin egen lyst.

Jeg får mange henvendelser fra begge køn, der er bekymrede over, at de ikke kan leve op til alle de nye orgasme-forventninger. Jeg hører ofte udtrykket "Jeg kan ikke give hende orgasme" eller "min mand kan ikke give mig orgasme" - så må jeg korrigere og fortælle, at orgasme er noget man kan få sammen. Evnen til at få orgasme skal man først og fremmest selv udvikle og derefter kan man opnå den i et samspil med partneren. Man kan ikke lægge ansvaret for sin lyst over på sin partner.

HB: Der tales af og til om orgasme-tyranni og orgasme-afhængighed. Jeg selv driver ikke nogen seksualklinik og skal ikke leve af, at nogen klager over, at de ikke kan få orgasme eller får for mange ved at færdes på internettet. Sagt på en anden måde: måske "orgasmeproblemer" er en social konstruktion med ivrige professionelle interessenter. Mange kvinder simulerer uden tvivl tit en orgasme, og mange mænd har uden tvivl mange elendige orgasmer; men man kan vel ikke med rimelighed forlange, at det skal være lige godt altid. Selvfølgelig er det fint at kunne få orgasme, hvis man gerne vil; men jeg er tilbøjelig til at mene, at internettet har bedre opdagelses- og eksperimenteringssteder end det kliniske rum med dets endeløse talen om "problemerne".

- Kan man observere et orgasmetabu i den vestlige kultur - og hvilken forskel er der $i$ den måde man opfatter de to kons orgasmer på?

VH: Hvis man skal tale om et orgasmetabu i dag, er det rettet mod mandens orgasme. Orgasme og udløsning er ikke nødvendigvis det samme, men det italesættes sjældent, hvordan manden kan opnå større nydelse i sexlivet. Mandens seksualitet betragtes som egoistisk, altid til stede og påtrængende - noget som skal holdes i ave. Den gode elsker er en mand, der kan holde sin egen udløsning tilbage og give kvinden nydelse, før han tænker på sig selv.

Den moderne mand har overtaget - eller fået pålagt - ansvaret for kvindens lyst og orgasme og det kan give ham problemer med at finde 
balancen mellem at være den servicerende og den begærlige.

I de senere år er antallet af henvendelser fra mænd, der ikke kan få udløsning sammen med en kvinde, vokset med foruroligende hast. Disse mænd har ingen problemer under onani, men sammen med kvinden vil kroppen ikke lystre. Samtidig får jeg flere og flere henvendelser fra kvinder, der savner at mærke mandens begær og de føler sig utilstrækkelige, hvis han har svært ved at få orgasme. Manglende udløsning hos en mand er et seriøst tabu og skammen rammer ikke bare ham, men også hans kvinde.

Groft sagt, har vi skabt et nyt tabu i de tilfælde, hvor det lykkes manden at undertrykke sin seksualitet alt for effektivt.

\section{Sex, politik og videnskab:}

- Hvilken rolle spiller seksualvidenskaben og konsforskningen for den 'folkelige' udvikling og forståelse af seksualitet?

HB: - Som landet ligger nu, er det forskningens opgave at sikre, at køn og seksualitet ikke altid på forhånd undersøges under det problematiskes synsvinkel. I den forbindelse må man også stille spørgsmålet om, hvem og hvad det er, der konstruerer køn og seksualitet som "problemer", der skal undersøges af "forskere" og "eksperter".

\section{- Hvilken rolle spiller skolen og bor skolen spille for seksualoplysningen?}

HB: - En stor rolle. Men jeg mener ikke, skolelærerne er bedst til at undervise i det emne. Egentlig er de principielt slet ikke egnede. Det er ikke smart at holde en alt for klinisk tone, når man skal snakke med unge om sex. Men det er heller ikke smart, at skolelærere skal stå og være være intimt-fortrolige kammerater med de unge, og så bagefter undervise i matematik, engelsk og geografi. I stedet skal skolerne rekvirere folk udefra, som har den fornødne kompetence i emnet "unge og sex" og den fornødne både nærhed og distance til de unge, idet de godt nok selv er tilpas unge, men ikke skal snakke med dem, de underviser i sex, også i næste time og i morgen. Det mest kvalificerede tilbud får man nu om dage hos foreningen Sex og samfund.

\footnotetext{
- Hvad er de politiske konsekvenser af den opfattelse of seksualitet som vi har $i$ Vesten $i$ dag?
} 
VH: Som jeg ser det, befinder vi os i en tid med stærkt modsatrettede strømninger - vi står i et vadested - måske et paradigmeskift. På den ene side er seksualiteten synlig som aldrig før. Medierne og ikke mindst internettet eksponerer sex i alle afskygninger. Subkulturerne blomstrer og der eksperimenteres på kryds og tværs.

Umiddelbart virker vi enormt frisindede, men under overfladen er seksualiteten stadig forbundet med skam, skyld og mange tabuer. Men det frisind som vi trods alt har tilkæmpet os i sidste århundrede, er kommet under stærkt pres de senere år. Strømninger genererer modstrømninger.

I takt med samfundets seksualisering vokser bekymringskulturen tilsvarende. Angsten for at alle disse nye tendenser og muligheder medfører sædernes forfald og ungdommens fordærv giver næring til en stigende nypuritanisme.

Religiøse, radikalfeministiske og politiske grupperinger finder sammen i krav om flere og flere restriktioner, censur og forbud. De seksualpolitiske debatter er ofte præget af personlige, følelsesmæssige og moralske argumenter. Seksualiteten ligger dybt forankret i os alle og er en del af vores personlighed. Netop derfor kan det være så svært at se ud over det personlige og anskue seksualitet $i$ et videre perspektiv og med større tolerance.

Jeg ved ikke hvor vi bevæger os hen - men jeg håber at det bliver i den retning, hvor det ægte frisind dominerer. Det frisind, der ikke kun tager udgangspunkt i ens egen seksualitet, men også respekterer andres ret til selv at definere deres og til at træffe nogle valg, som man ikke selv ville gøre.

HB: Verden er stor og mangfoldig, selv "Vesten" er det. I Danmark finder moralisterne især inputs og moralsk opbakning i Sverige og i verdens måske mest bigotte land, England. Selv nordmænd og nordkvinder er stridbare og ikke altid så nemme at styre. Og selv i Tyskland fabler ingen for alvor om at forbyde kvinder at handle, heller ikke med seksuelle tjenesteydelser, eller forbyde pornografi.

De danske, svenske og engelske moralister vil have kontrol, forbud og begrænsninger. På RUC har man i realiteten installeret en automatisk telefonsvarer, hvis mandlige $\mathrm{og}$ kvindelige stemmebånd råber "Det er skrækkeligt, det skal forbydes!" hver gang medierne ringer og spørger. Og det gør medierne, hver gang! Der er en sær sammenhæng mellem venstrefløj og seksuel moralisme.

Der er også en sær sammenhæng mellem moralisme og tidens 
førende universitetsideologi. Mænd er positioneret i et hierarkisk overordnet og dikotomisk forhold til kvinder, hedder det, ligesom hvide er det i forhold til sorte, danskere er det til indvandrere, heteroseksuelle er det til queere osv. Undertrykkelse, marginalisering og udgrænsning er obligatoriske ord, ligeledes sexisme, racisme, xenofobi, heteronormativitet, nationalisme etc. Plus naturligvis "Magt", der her optræder i en Foucault light udgave. De forskellige hierarkiserede dikotomier støtter, gennemtrænger og konstituerer hinanden, fremhæves det; sig navnet: intersektionalisme! Men måske ingen af delene passer, hverken hver for sig eller tilsammen. Måske man skulle holde øjnene åbne for alt det andet, der også er, eller er der i stedet, frem for bare at projicere dette lirumlarum ud over verden, og frem for kun at lede efter noget, der kan bekræfte den intersektionalistiske akademiske papegøjes plapren.

Man kunne håbe, at denne 30 år gamle politisk-ideologiske mode snart havde gentaget sig selv til døde. Man kunne måske også håbe, at der kom en politisk orientering og et politisk parti, der kombinerede en høj grad af økonomisk og social ansvarlighed over for fattige og svage, med en udstrakt frihed til at folk kunne leve som de lyster, omend moralsk-etisk ansvarligt. Idealet kunne være at sikre de økonomiske, sociale, uddannelsesmæssige betingelser for at folk kunne mene og leve som de vil, så længe de ikke for alvor skader nogen med det. Det parti findes endnu ikke i det danske landskab. 